\title{
After Brüstle: EU accession to the ECHR and the future of European patent law
}

\author{
Aurora Plomer* \\ Professor of Law and Bioethics, The University of Sheffield, UK
}

The aim of the Directive on Biotechnological Inventions $1998^{1}$ was to harmonize national patent laws in order to bolster Europe's competitiveness in fields involving biotechnological applications. From the beginning, the Directive was met with a barrage of opposition from politicians, political lobbies, religious organizations and academics who called for the need to ensure that ethical principles would not be sacrificed on the altar of commerce and market forces. ${ }^{2}$ Human rights were specifically invoked to justify the importation of moral exclusions into the Directive. ${ }^{3}$ Yet, little thought was given at the time to the implications and the potential tensions created by the lack of integration between the European Union (EU) and the Council of Europe (CoE) legal orders and courts. This paper analyses and evaluates how the historical tensions are manifested in the paradoxical judgment of the Grand Chamber of the European Court of Justice (CJEU) in the Brüstle case. ${ }^{4}$ It is suggested that the CJEU ruling represents a disproportionate interference with the autonomy of Member States and is inconsistent with the degree of autonomy vested in Member States by the European Convention legal order. More generally, the paper uses the Brüstle case as a lens through which to analyse and evaluate the potential impact of the current proposal for the EU's accession to the European Convention on Human Rights (ECHR) on the resolution of emerging tensions.

* I am particularly grateful to Ian Cram, Graeme Dinwoodie, Alastair Mowbray and Sionaidh Douglas-Scott for their comments. I also benefited from the comments of participants on an earlier version of this paper which I gave at the Oxford Intellectual Property Research Centre on 10 November 2010.

1. Directive 98/44/EC of the European Parliament and of the Council of 6 July 1998 on the legal protection of biotechnological inventions OJ L 213/13 ('the Directive').

2. See eg D Beyleveld and R Brownsword, Mice, Morality and Patents (Common Law Institute of Intellectual Property 1993). R Brownsword, W Cornish and M Llewelyn, Law and Human Genetics: Regulating a Revolution (Hart 1998).

3. See Case C-377/98 Kingdom of the Netherlands v European Parliament and Council of the European Union ECR I-07079 and Preamble to the Directive: 'Whereas pursuant to Article F(2) of the Treaty on European Union, the Union is to respect fundamental rights, as guaranteed by the European Convention for the Protection of Human Rights and Fundamental Freedoms signed in Rome on 4 November 1950 and as they result from the constitutional traditions common to the Member States, as general principles of Community law (para 43).'

4. Case C-34/10 Oliver Brüstle v Greenpeace e.V. [2011] OJ C 362/5 Judgment of the Court (Grand Chamber) of 18th of October 2011. The case is a reference for a preliminary ruling under Article 267 TFEU from the Bundesgerichtshof (Germany), made by decision of 17 December 2009 on the interpretation and scope of application of Article 6(2)(c) of Directive 98/44/EC. 
Keywords: EU Directive on Biotechnological Inventions 98/44/EC, moral exclusions, Article 6(2)(c), embryonic stem cells, human dignity, Brüstle, EU accession to the ECHR, European Convention on Human Rights, EU Charter of Fundamental rights, Council of Europe's Convention on Human Rights and Biomedicine

\section{INTRODUCTION}

Fundamental human rights are undoubtedly intended to play an important part in the legal construction of the scope of moral exclusions on biotechnological patents detailed in Article 6 of the EU Directive on Biotechnological Inventions (hereafter 'the Directive'). The Preamble to the Directive itself recalls the obligation arising from the European Union's Treaty 'to respect fundamental rights, as guaranteed by the European Convention on Human Rights ... 1950 and as they result from the constitutional traditions common to the Member States, as general principles of Community law'. Since the adoption of the Lisbon Treaty, ${ }^{6}$ the legal imperative to align the construction of moral exclusions on patents to fundamental human rights has been, if anything, strengthened by two significant changes. First, the Lisbon Treaty requires that the European Union accedes to the European Convention on Human Rights. ${ }^{7}$ Secondly, the Lisbon Treaty formally recognizes the Charter of Fundamental Rights of the European Union, assigned the same value as the Treaties. ${ }^{8}$ Both developments raise a number of important questions which potentially impact on the interpretation of moral exclusions in the Directive. One set of questions concerns the implications of accession as regards juridical hierarchy and authority on aspects of EU law touching on fundamental human rights protected by the Convention. Of the Court of Justice of the European Union (CJEU) and European Court of Human Rights (ECtHR), which court will have ultimate authority on the protection of fundamental human rights and their application to the construction of moral exclusions on biotechnological patents in EU law? The other set of questions concerns the normative integration of the dual body of 'primary' norms contained in the EU Charter and the Convention and its Protocols respectively. How are differences in the wording of discrete rights or the absence of a direct counterpart for some of the rights specified in each instrument to be resolved? In the event of conflict or ambiguity as between the two

5. Recital 43. At the time the obligation arose under Article F(2) of the Treaty on European Union.

6. Treaty of Lisbon amending the Treaty on European Union and the Treaty establishing the European Community, signed at Lisbon, 13 December 2007 [2007] OJ C 306/1. The Treaty entered into force on 1 December 2009. For an overview of the constitutional significance of the Lisbon Treaty see P Craig, 'Institutions, Power and Institutional Balance', in P Craig and $\mathrm{G}$ de Burca (eds), The Evolution of EU Law (2nd edn, Oxford University Press, Oxford 2011) 41-84.

7. Under Article 6(2) TEU and Protocol No. 14 to the European Convention on Human Rights: Art 59(2) ECHR: 'the EU may accede'.

8. Article 6(1) TEU states that 'The Union recognizes the rights, freedoms and principles set out in the Charter of Fundamental Rights of the European Union of 7 December 2000, as adapted at Strasbourg, on 12 December 2007, which shall have the same legal value as the Treaties'. The Charter had been proclaimed a decade earlier on 7 December 2000, but was not legally binding on Member States. For an analysis of the significance of the Charter's incorporation into the Treaty see S Douglas-Scott, 'The European Union and Human Rights after the Treaty of Lisbon' (2011) 11(4) Human Rights Law Review 645. 
instruments, which norms should have precedence over the others? Specifically, how is the interpretation of moral exclusions in the Directive affected by these developments? The concrete mechanisms and procedures put in place to address these questions will be critical to the degree of judicial integration and normative coherence which will be achieved by EU accession to the ECHR and could have profound implications on the future construction of moral exclusions in European patent law.

The first part of this paper situates the current proposals for accession against the evolution of human rights protection in the European Union, documenting recurrent concerns over the relative autonomy of national supreme courts and the two supranational courts of the EU and Council of Europe respectively on the constitutional balance between national, EU and $\mathrm{CoE}$ legal orders. The second part details the current proposals for accession, ${ }^{9}$ teasing out the architectural structure and implications for institutional integration and hierarchy of legal norms in Europe. The third part analyses the legal basis of the scope of exclusions on patents on human embryonic stem cells (hESC) in the judgment of the Grand Chamber of the CJEU in the Brïstle case and questions the judgment's compliance with the protection of fundamental human rights. The last part considers the avenues for appeal to the European Court of Human Rights post-Lisbon.

\section{PART 1 - EVOLUTION OF HUMAN RIGHTS PROTECTION IN THE EU}

In an illuminating chronicle of the evolution of the protection of fundamental rights in the EU, Gráinne de Burca shows that the range of questions which are the subject of current negotiations on the modalities of accession of the EU to the ECHR after Lisbon, were very much at the centre of the early discussions which led to the adoption of the EEC Treaty. ${ }^{10}$ Whilst there was general agreement in the immediate aftermath of World War II that the protection of fundamental rights was central to the project of European integration, there were marked differences as to how this should be achieved. One 'expansive' approach, endorsed by the Comité d'Etudes pour la Constitution Europeenne (CECE), ${ }^{11}$ was for the new Community to act as a guardian of the ECHR and to be vested with the power to intervene in the event of serious violations of fundamental rights by Member States. ${ }^{12}$ The CECE proposal further envisaged that the new Community would have a Supreme Court which would act both as a Constitutional Court and a Court of Appeal, with jurisdiction over individual rights of petition for breaches of Treaty law but no specific jurisdiction over human rights issues.

9. The 8th Working Meeting of the CDDH Informal Working Group on the Accession of the European Union to the ECHR (CDDH-UE) with the European Commission, Draft Legal Instruments on the accession of the European Union to the ECHR. Draft instrument and explanatory report of 19th July 2011, CDDH-UE (2011) 16, Final.

10. G de Burca, 'The Evolution of EU Human Rights Law', in P Craig and G de Burca (eds), The Evolution of EU Law (Oxford University Press, Oxford 2011) 465-95.

11. The CECE acted as a think-tank on the process of drafting the constitution ('statute') of the European Community and was established before the Ad Hoc Community which was formally charged with drafting the Treaty. On the composition of the CECE Committee and its close ties with the Council of Europe, see de Burca, op cit, n 10 at 468.

12. Or if requested by the constitutional authorities of a Member State 'to assist the latter with a view to maintaining the constitutional order, democratic institutions or man's fundamental liberties', para 7 of CECE Resolution. Projet de Statut de la Communaute Politique Europeenee: Travaux preparatoires (European Movement, Brussels 1952). Cited in de Burca, op cit, n 10. 
The assumption was that Member States had primary responsibility for the protection of fundamental rights, for which they were answerable to the ECtHR, although the European Community was envisaged as a "kind of strong-arm back-stop' 13 with a monitoring, intervention role in the event of serious violations of human rights by Member States.

By contrast, the recommendations of the Ad Hoc Assembly formally charged with the task of drafting the European Political Community (EPC) treaty envisaged that the Community itself could be a potential violator of human rights, and therefore that its supervisory role over violations of human rights should be limited and subject to oversight by the ECHR. The drafters discussed various options to ensure that the ECtHR would have jurisdiction over violations of human rights by the Community, including accession of the Community to the ECHR and amendments to the statute of the Council of Europe. ${ }^{14}$ In debates which are echoed in the current negotiations over the modalities of accession, concerns were expressed over the scope of jurisdiction of the community court and the possibility of it impinging on the jurisdiction of the ECtHR. ${ }^{15}$ The committee wrestled with the question of whether the Community court should be seen as a 'domestic tribunal' for the purpose of exhaustion of domestic remedies for the ECtHR, and determined that it would be inappropriate to make it compulsory for a dispute concerning human rights to be remitted first to the Community court. ${ }^{16}$ The compromise solution reached to minimize conflict between the two courts was to grant the Community court jurisdiction to hear actions by individuals against the Community institutions for violations of the ECHR. But the Community court was to 'renounce judgment' where the dispute involved a question of principle as to the interpretation of the ECHR.

The draft EPC Treaty, including the system of human rights protection, was short lived as the early ambitious project of promoting European political integration and human rights protection through an EC treaty collapsed with the advent of the cold war and the failure of the European Defence Treaty. The process of European integration was revived in 1955 with an agreement by foreign ministers to narrow the focus to economic integration and the establishment of a common market. ${ }^{17}$ The outcome was the European Economic Community Treaty and European Atomic Energy Treaty in 1957, which adhered strictly to the economic mandate and excluded references to human rights as a way of avoiding political controversy. Protection of human rights was left to national constitutional systems and the ECHR system. The revival of a human rights remit for the European Union was subsequently brought about initially through judicial intervention in a series of landmark cases by the CJEU in the 1960 s and 1970 s, ${ }^{18}$ in which the CJEU declared that respect for fundamental rights, inspired by the common constitutional traditions of the Member States and international human rights treaties, was part of the general principles

13. De Burca, op cit, n 10 at 471.

14. De Burca, op cit, n 10 at 472 .

15. The concerns were voiced by the German delegate. See de Burca, op cit, n 10 at 473 , footnote 12 .

16. De Burca, op cit, n 10 at 473 .

17. The 'Messina Resolution' adopted in Messina, 1-3 June 1955.

18. In a trio of cases: Case 29/60 Stauder v City of Ulm [1969] ECR 419; Case 11/70 Internationale Gesellschaft v Einfuhr und Vorratsstelle für Getreide und Futtermittel [1970] ECR 1125; Case 4/73 Nold v Commission [1974] ECR 491, following Case 6/64/ Flaminio Costa $v$ ENEL [1964] ECR 585. 
of Community law. The CJEU further claimed jurisdiction to hear claims for breaches of such rights arising from community acts and policies, prompted by concerns to preserve the autonomy and supremacy of community law over national constitutional law. ${ }^{19}$ In the next decade, the political momentum to formally integrate the protection of fundamental human rights in the Treaties grew stronger. ${ }^{20} \mathrm{In}$ 1992, for the first time, the revised constitutional framework of the European Union formally recognized human rights as part of EU law in the Maastricht Treaty. ${ }^{21}$ Successive treaties have since expressly recognized the obligation of the EU to protect fundamental rights, ${ }^{22}$ culminating in the adoption of the EU Charter of Fundamental Rights and Freedoms, ${ }^{23}$ proclaimed, but not-ratified, in 2000 and legally binding since the adoption of the Lisbon Treaty. Article 6(2) of the Lisbon Treaty specifically requires that 'the EU shall accede to the ECHR' but does not specify the modalities of accession and procedures for case-sharing and/or referral as between national courts, the CJEU and the ECtHR. ${ }^{24}$

The debates which have taken place post-Lisbon over the modalities of the EU's accession to the ECHR continue to echo the historical and political tensions on the relative autonomy, constitutional balance and ultimate authority of the triangle of national courts and the two supra-national courts. ${ }^{25}$ Statements made by politicians, officials of the EU and the presidents of the two courts imply that the accession will create a form of hierarchical ordering and vertical integration of the two supranational courts, with the European Court of Human Rights acting as the ultimate guardian of fundamental human rights in Europe. The European Parliament's website states that the accession will enable ' ... the European Court of Human Rights in Strasbourg to verify the compliance of EU acts with the ECHR, which will also serve to

19. De Burca, op cit, n 10 at 478.

20. That is, through the adoption of the 'European Political Cooperation' on foreign policy in 1970, the Declaration of European identity in 1973, the Copenhagen Declaration in 1978 and the 1977 Joint Declaration of the European Parliament, Council and Commission on fundamental rights affirming case law of the CJEU. See A Williams, EU Human Rights Policies: A Study in Irony (Oxford University Press, Oxford 2004).

21. Article $\mathrm{F}(2)$ of the Maastricht Treaty states that 'The Union shall respect fundamental rights, as guaranteed by the European Convention for the Protection of Human Rights and Fundamental Freedoms signed in Rome on 4 November 1950 and as they result from the constitutional traditions common to the Member States, as general principles of Community law'. 22. Though in some scholars' view, originally mainly as 'empty rhetoric'. See the seminal article by Alston and Weiler who proposed the creation of an institutional framework with powers of oversight, monitoring and enforcement to give substance to the rhetoric: P Alston and JHH Weiler 'An "Ever Closer Union" in Need of a Human Rights Policy' (1998) 9(4) Eur J Int Law 658.

23. There is a voluminous body of literature on the adoption and evolution of the Charter. See G Di Federico, The EU Charter of Fundamental Rights (Springer, Dordrecht 2011).

24. The procedures for the conduct of negotiations and agreements with international organizations and the EU are set out in Art 218 TFEU.

25. For general discussions of the relationship between the EU and ECHR systems, see S Greer and A Williams, "Human Rights in the Council of Europe and the EU; Towards "Individual", “Constitutional” or "Institutional” Justice?' (2009) 15(4) European Law Journal 462; O De Schutter, 'The Two Europes of Human Rights: The Emerging Division of Tasks between the Council of Europe and the European Union in Promoting Human Rights in Europe' (2008) 14 CJEL 509; F Van den Berghe, 'The EU and Issues of Human Rights Protection; Same Solutions to More Acute Problems?' (2010) 16 ELJ 112. 
enhance the protection of fundamental rights within the European Union'. ${ }^{26}$ The Council of Europe's website describes the accession as a 'historical step' for several reasons, notably the fact that, as a result of acceding to the ECHR, the Union 'will be integrated' into the ECHR fundamental rights protection system, and 'the Union will be bound to respect the ECHR and placed under the external control of the European Court of Human Rights'. ${ }^{27}$ Similarly, the Vice-President of the European Commission said in her address to the European Parliament in March 2010 that: 'By acceding to the Convention, the European Union itself puts its weight behind the Strasbourg system of external judicial control in the area of fundamental rights by integrating its legal order fully and formally to that control system'. ${ }^{28}$ A parallel statement issued by the Secretary General of the Council of Europe and President of the European Court of Human Rights in May 2010 welcomed accession as a move which would further strengthen the protection of human rights in Europe 'by submitting the EU's legal system to independent external control with regard to the rights protected by the Convention, as interpreted by the Court in its case law'. ${ }^{29}$

Beyond political rhetoric, achieving constitutional balance through the submission of the EU system to the external control of the Convention system is critical in addressing concerns about the (lack of) democratic accountability, the political legitimacy/ deficit of EU institutions, and the 'constitutional asymmetry' between Member States and the EU. ${ }^{30}$ The questions under discussion in the current round of negotiations on the modalities of accession of the EU to the ECHR go deep into the heart of issues touching on the political legitimacy of the new institutional framework, the sphere of competence of the respective courts, and ultimately the constitutional balance between the two supra-national courts, national laws and the two supra-national legal systems. They include

the scope of the accession (including questions related to the accession to the various protocols, to admissible reservations etc.), the technical adaptations needed to the ECHR text, the participation of the EU in CoE bodies involved in the ECHR system (including its financial participation to the system), and the possible further adaptations of the ECHR system to the specificities of the EU system. ${ }^{31}$

The key aspects of the proposals are discussed below.

26. <http://www.europarl.europa.eu/parliament/public/staticDisplay.do?id=137\&pageRank= $3 \&$ language $=\mathrm{EN}>$.

27. <http://www.coe.int/t/dghl/standardsetting/hrpolicy/CDDH-UE/>.

28. Vivian Reding, 'The EU's Accession to the European Convention on Human Rights: Towards a Stronger and More Coherent Protection of Rights in Europe', speech to European Parliament, 18 March 2010: <http://ec.europa.eu/commission_2010-2014/reding/pdf/speeches/ speech_20100318_1_en.pdf>.

29. Joint statement issued in Strasbourg, 31 May 2010: Press Release - 437(2010).

30. Including growing concerns at the expanding jurisdiction of the CJEU and the attending gradual and deep structural transformation and 'constitutionalization' of the EU through the judicial doctrines of the CJEU. See JHH Weiler, The Constitution of Europe: 'Do the New Clothes Have an Emperor?' and Other Essays on European Integration (Cambridge University Press, Cambridge and New York 1999). See also M Wilkinson, 'Who's Afraid of a European Constitution?' (2005) 30(2) European Law Review 297 and P Linseth, Power and Legitimacy (Oxford University Press, Oxford 2010) on the disconnect in the integration process between the need for supra-national regulatory power and the persistence of national constitutional legitimacy.

31. <http://www.coe.int/t/dghl/standardsetting/hrpolicy/CDDH-UE/>. 


\section{PART 2 - MODALITIES OF EU ACCESSION TO THE ECHR}

The proposed framework is the product of 'an informal working group' (CDDH-UE) which was appointed to elaborate a draft agreement following negotiations between the Commission and the Steering Committee on Human Rights of the Council of Europe. ${ }^{32} \mathrm{~A}$ 'final' draft instrument and explanatory report was adopted by the CDDH-UE on 24 June 2011. But this is only the first stage of what is likely to prove a very long and testing process. The Draft Accession Agreement must secure the approval of the Committee of Ministers and Parliamentary Assembly of the Council of Europe and EU institutions, as well as all Member States of the Council of Europe and European Union respectively, in accordance with the procedures laid down in the respective treaties of each legal order as well as the constitutional requirements of each of the contracting States. ${ }^{33}$

The balance of power and competences of the two courts may well alter as the proposal continues its complex routing for institutional and State approval, particularly as the CDDH-UE proposal leans towards the early Ad Hoc Committee's vision of a limited role for the EU in the protection of fundamental rights, and subordination of the CJEU to the ultimate authority of the ECHR in disputes over violations of fundamental human rights. ${ }^{34}$ Responsibility for judicial review of human rights compliance is left with the national supreme courts of Member States, and ultimate authority over human rights violations with the ECtHR. But the detailed proposals also create a complex nexus of mechanisms for intermediary intervention and review by the CJEU and subsequent intervention in individual petitions to the ECtHR. ${ }^{35}$

32. The terms of reference of the Ad Hoc Steering Committee (CDDH) were adopted by COE Committee of Ministers, on 26 May 2010. The CDDH was charged to draft, in collaboration with the EU, a legal instrument for accession. On the EU side, the Council of the EU adopted a Decision on 4 June 2010 authorizing the European Commission to negotiate an agreement for the EU to accede to the Convention. Throughout the process, the Commission has regularly consulted the Working Party on fundamental rights, citizens' rights and free movement of persons ('FREMP'), which had been appointed as the special committee in accordance with Article 218 (4) TFEU. On 19 July 2011, a 'final' version of the draft legal instruments on the Accession of the European Union to the ECHR was adopted: CDDH-UE (2011) 16 final.

33. Article 218 (8) TFEU, states that the agreement on accession shall be concluded unanimously by the Council. Pursuant to Article 218 (6) (a) (ii) TFEU, the Council shall obtain the consent of the European Parliament for concluding the agreement on the EU accession. Article 218 (10) TFEU provides for the European Parliament to be fully informed of all stages of the negotiations. The agreement would also have to conform separately with the ECHR requirements and approved by all 47 existing contracting parties to the ECHR in accordance with their respective constitutional requirements. Protocol No. 8 of the Treaty of Lisbon set out further requirements for the conclusion of the Accession Agreement. Protocol No. 14 to the ECHR, adopted in 2004 and entered into force on 1 June 2010, amended Article 59 of the Convention to allow the EU to accede to it.

34. Before the EU gives consent, the finalized draft of the agreement/instruments will be submitted by the Commission to the CJEU for an opinion on the compatibility with the Treaties. The European Parliament will have to approve the whole 'package' (Art 218(6)(a)(ii) TFEU) and the unanimous approval of all Member States is also required (Art 218 (8) TFEU). In addition, each Member State will have to approve the agreement in accordance with its own constitutional requirements.

35. <http://www.coe.int/t/dghl/standardsetting/hrpolicy/CDDH-UE/CDDH-UE_documents/ CDDH-UE_2011_04_en.pdf>. The draft legal instrument should be submitted to the Committee of Ministers of the Council of Europe by 30 June 2011. The process of appointment and remit of 
In the 'final' draft agreement, rulings of the CJEU will be subject to the external control of the ECtHR. ${ }^{36}$ Furthermore, individuals will have the right to submit the acts, measures or omissions of the EU institutions, bodies or agencies to the external control of the Strasbourg Court, ${ }^{37}$ and the European Union and its institutions, including the CJEU, will be legally bound by the obligations arising from the Convention and the Protocols. ${ }^{38}$ The explanatory notes state that 'this is all the more important since the EU Member States have transferred substantial powers to the EU'. ${ }^{39}$ In order to facilitate accession and minimize delays and cumbersome amendments to the text of the ECHR, ${ }^{40}$ the proposal is that the EU would be given the status of a 'High Contracting Party' ${ }^{41}$ to the Convention and subject to the obligations imposed by the ECHR in respect only of measures for which it has competence under EU law. ${ }^{42}$ In what may well reignite concerns over the EU's expanding spheres of competence and powers, the proposal suggests that wherever Convention texts refer to 'States', 'State Parties' or 'State' 'they shall be understood as referring also the European Union' ${ }^{43}$ The explanatory notes justify the 'linguistic' interpretive approach 'to allow for an immediate accession' on the grounds that the Convention, when drafted, was meant to apply only to contracting parties who are also Member States of the Council of Europe, and the EU is neither a State nor a member of the CoE. ${ }^{44}$

The process envisaged by the draft agreement is not quite the inverse, but a variant of the 'preliminary' referral option which had been floated in an earlier draft which would have given the CJEU a first opportunity to rule on the compatibility of EU law with Convention rights. ${ }^{45}$ Article 4.3 of the earlier draft agreement proposed that:

Prior to a decision by the European Court of Human Rights on the merits of a case in which the European Union is a co-respondent, the Court of Justice of the European Union shall have the opportunity to rule, if it has not yet done so, on the [validity/conformity] of the act of the European Union [if the question of the validity/conformity is raised by the applicant] with [regard to] fundamental rights as set out in the notification of the application to the parties.

The 'final' draft agreement sets out an alternative procedure whereby the European Union or a Member State may become a co-respondent by decision of the Strasbourg

the EU-CoE working group on the draft legal agreement is set out in the Council of Europe's website as follows: <http://www.coe.int/t/dghl/standardsetting/hrpolicy/CDDH-UE/CDDHUE_documents_en.asp $>$.

36. Preamble, Draft Agreement (supra).

37. Preamble and Article 1(2)(c).

38. In respect only of measures for which the EU has competence (Article 1(2)(c)). Nothing in the Treaty shall enlarge the competence of the EU (reflecting the requirement under Article 2 of Protocol 8 of the Lisbon Treaty that the accession of the EU shall not affect its competences or the powers of its institutions): explanatory notes, III (I)(21).

39. Explanatory Report, at para I(1)(5). The note further adds that the competence of the Strasbourg court to assess the conformity of EU law with the provisions of the Convention will not prejudice the principle of the autonomous interpretation of EU law.

40. Which would require approval by each of the Members of the Council of Europe.

41. Article 1(2)b.

42. Article 1(2)c, and Article 9(2) TEU 'The Union shall accede to the [Convention]. Such accession shall not affect the Union's competences as defined in the Treaties'.

43. Article 1(2)d.

44. Draft Explanatory Report to the Agreement on the Accession of the EU to the ECHR, para I.3.

45. I am grateful to Gráinne de Burca for bringing this point to my attention. 
Court. The mechanism is considered necessary to accommodate the specific situation of the EU as a non-State entity with an autonomous legal system alongside national legal systems, whereby acts adopted by the EU institutions may have to be implemented by Member States. ${ }^{46}$ The agreement envisages that the co-respondent mechanism will be triggered in circumstances where an application notifying an alleged violation is made to the Court by one or more Members of the EU, but not the EU itself, if it appears to the (Strasbourg) Court that the alleged violation calls into question the compatibility of a provision of primary or secondary EU law with the Convention. ${ }^{47}$ It is suggested that this may occur, for instance, where the alleged violation could only have been avoided by a Member State disregarding an obligation under EU law 'for example where an EU provision leaves no discretion to a Member State as to its implementation at national level'. ${ }^{48}$ The CDDH expressly justifies the introduction of the co-respondent mechanism as a way to ensure that the EU is legally bound by a judgment of the Strasbourg court in the event of the Court finding a violation of the Convention. ${ }^{49}$ More generally, the co-respondent mechanism is 'a way to avoid gaps in participation, accountability and enforceability in the Convention system'. ${ }^{50}$

Furthermore, the co-respondent mechanism will enable the ECtHR to give an opinion on the compatibility with the Convention of the act complained of by the applicant in circumstances where there has been no preliminary referral to the CJEU on the interpretation or validity of the act at issue. The explanatory notes make it clear that applicants will only need to exhaust their remedies in national courts without appealing to the CJEU before the case is remitted to the Strasbourg Court, since the preliminary referral procedure "cannot be considered a remedy that an applicant must exhaust before making an application to the Court' because referral is at the discretion of the national courts. ${ }^{51}$ Whether the European Union will approve the draft agreement in its present form is not altogether clear. At the meeting of COREPER on 6 October 2011 some delegations expressed reservations as to the content of the proposed draft accession agreement. Subsequently, on 12-14 October 2011 CDDH took note of the fact that the Union could not express a unanimous position on the draft and reported accordingly to the Committee of Ministers of the Council of Europe. ${ }^{52}$ According to Luca de Matteis, seconded national expert at the General Secretariat of the European Union, questions still open in relation to the draft accession instruments include the scope of the EU's accession, in particular concerning submission to the ECtHR's jurisdiction, adaption to the non-State nature of the EU, the extent of the ECtHR's 'extraterritorial' jurisdiction in matters concerning the EU, cases and conditions for unclenching the co-respondent mechanism. ${ }^{53}$ But whatever form the agreement

46. Para 32.

47. Para 42.

48. Para 42, emphasis added.

49. Ibid. Contrast third party interventions, where the party is not bound by the judgment (para 39).

50. Para 33.

51. Para 57.

52. See Council of the European Union, Accession of the Union to the European Convention for the Protection of Fundamental Rights and Freedoms - State of Play 18117/11, Brussels 6 December $2011<$ http://register.consilium.europa.eu/pdf/en/11/st18/st18117.en11.pdf>.

53. Luca de Matteis, 'Accession of the EU to the ECHR: Next Steps in the Process', paper presented at ERA's conference on EU Accession to the ECHR, Brussels, 30 January 2012. See also Council of the European Union record of state of play on 6 December 2011 (op cit, n 52) at para 7. 
takes as to the precise role and prior involvement of the CJEU and procedures in disputes concerning compliance of EU law with the ECHR, the clear legal obligation on the EU, since the adoption of the Lisbon Treaty, is to ensure that EU law is compliant with the ECHR. The European Court of Human Rights, as guardian of the ECHR, must inevitably become a final court of appeal in disputes raising questions as to the compatibility of EU law (including CJEU rulings) with the ECHR.

\section{PART 3 - HUMAN RIGHTS IN EU LAW ON BIOTECHNOLOGICAL INVENTIONS}

Prior to formal recognition of Convention rights in the Maastricht Treaty (1992), the European Court of Justice had declared respect for fundamental rights to be part of the general principles of Community law in a trio of landmark cases in the 1970s. ${ }^{54}$ The context was the controversies surrounding the Court's pronouncement of the supremacy of EU law in Costa $v$ ENL, prompting political and legal concerns about the risk of compromising constitutionally protected fundamental rights in national laws. The principles enunciated by the Court in the trio of cases declaring the primacy of fundamental rights in Community law were the Court's response to protect the autonomy of Community law vis-à-vis national laws. Whilst asserting the supremacy and autonomy of EC law as a source of rights, the Court also declared that its understanding of fundamental rights would be informed by the common constitutional traditions of the Member States and international human rights treaties to which they are a party. ${ }^{55}$

The Netherlands case ${ }^{56}$ was the first case in which the EU court was called upon to review the compatibility of European Union law in the Directive on Biotechnological Inventions (1998) with fundamental human rights. The applicants had sought annulment of the Directive, inter alia, on the grounds that the Directive was in breach of the fundamental right to respect for human dignity. In his Opinion, the Advocate General, Justice Jacobs, had acknowledged that respect for fundamental rights must be ensured in the Community legal order and that the right to human dignity is perhaps the most fundamental right of all, ${ }^{57}$ noting that the text of the Directive itself obliges the Union to respect fundamental human rights

... pursuant to Article $\mathrm{F}(2)$ of the Treaty on European Union, the Union is to respect fundamental rights, as guaranteed by the European Convention for the Protection of Human Rights and Fundamental Freedoms signed in Rome on 4 November 1950 and as they result from the constitutional traditions common to the Member States, as general principles of Community law. ${ }^{58}$

Yet, in a telling omission in the Court's judgment, there is no reference to the parallel jurisprudence of the European Court of Human rights as an interpretive guide to the

54. Case 29/69 Stauder v City of Ulm [1969] ECR 419; Case 11/70 Internationale Handelsgesellschaft $v$ Einfuhr und Vorratsstelle fur Getreide und Futtermittel [1970] ECR 1125; and Case 4/73 Nold v Commission [1974] ECR 491.

55. De Burca, op cit, $\mathrm{n} 10$ at 478.

56. Case C-377/98 Kingdom of the Netherlands $v$ European Parliament and Council of the European Union ECR I-07079.

57. At para 197.

58. Para 43, Preamble. 
Convention, let alone as a superior source of law. Instead, the EU Court expressly stated that it had jurisdiction to review compliance of EU law with fundamental rights human rights 'to ensure that the right to human dignity and integrity is observed'. 59

Notwithstanding the ambiguous role and status of the EU court vis-à-vis the Strasbourg court pre-Lisbon and pre-accession, and the absence of references to the ECtHR jurisprudence in the EU court's judgments on the Directive before Brïstle, the substance of the rulings on the interpretation of moral exclusions in the Directive could arguably previously be aligned to the ECHR. By contrast, it is arguable that the EU Court's 'wide' reading of the exclusion in Brüstle, claimed by the Court to be necessary to comply with respect for human dignity, creates serious tensions with the ECHR. ${ }^{60}$ As such, the judgment provides an interesting case to analyse the implications of accession for the construction of moral exclusions in the Directive post-Lisbon. The next section reviews the case law on the Directive before Brüstle.

\section{Fundamental human rights and the Directive: ECJ case law before Brüstle}

The subject matter of the preliminary reference in the Brüstle case is the specific moral exclusion on 'industrial and commercial uses of human embryos' in Article 6(2)(c) of the Directive. Prior to the Brüstle ruling, the meaning and scope of exclusion of Article $6(2)(c)$ had been a source of uncertainty and litigation almost as soon as the Directive was adopted. The publication of Jamie Thomson's seminal article on the derivation of human embryonic stem cells in Science only months after the adoption of the Directive raised the question of the precise reach of the exclusion. ${ }^{61}$ Specifically, did the exclusion in Article 6(2)(c) extend to cells (and their use) obtained from human embryos? The question was extensively litigated through the tribunals of the European Patent Organization $^{62}$ in a number of cases, starting with the Edinburgh case ${ }^{63}$ and culminating in the landmark ruling of the Enlarged Board of Appeal in the WARF case. ${ }^{64}$ In the European Union legal system Oliver Brüstle's appeal to the German Supreme Court against the invalidation of a national patent on neural precursor cells was the basis

59. Case C-377/98 ECR-I-07079 at para 70. For an insightful analysis of the difficulties raised by the overlap in jurisdiction and competence of the CJEU and the ECHR see C Smith and T Fetzer, 'The Uncertain Limits of the European Court of Justice's Authority: Economic Freedom versus Human Dignity' (2004) 10 Colum. J Eur L 445; also, JHH Weiler, 'A Constitution for Europe? Some Hard Choices' (2002) 40 J. Common Mkt. Stud. 563, 573; and A Williams, 'The (Im)possibility of the European Union as a Global Human Rights Regime', in R Brownsword (ed), Global Governance and the Quest for Justice: Volume 4, Human Rights (Hart, Oxford 2004).

60. See infra.

61. James Thomson et al., 'Embryonic Stem Cell Lines Derived from Human Blastocysts', (1998) 282 (5391) Science, 6 November 1145.

62. The European Patent Organization had transposed the specific exclusion into the EPC. See notice dated 1 July 1999 concerning the amendment of the implementing regulations of the European Patent Convention: [1990] O.J.E.P.O, at 437 and 573.

63. Decision of the Opposition Division of 21 July 2003 on European patent No. EP0695351 (University of Edinburgh).

64. Case G2/06. Decision of the Enlarged Board of Appeal of 25th of November 2008 rejecting the claims of WARF's European Patent Application No. 96903521.1. O.J.E.P.O. 2009, 309. 
of the referral to the CJEU. ${ }^{65}$ The Grand Chamber of the EU court read the exclusion very widely and cited its earlier jurisprudence on the Directive in the Netherlands and Italy cases to justify its ruling. But the Court's reasoning is difficult to reconcile with the principles applied in these cases.

In the Netherlands case, the EU court had construed the provisions in Article 5 and Article 6(1) of the Directive as guaranteeing protection of human dignity. Specifically, the court held that human dignity was 'safeguarded' and 'guaranteed' in Article 5(1) of the Directive by the distinction between the patentability of the human body itself, its discovery or its elements in a natural environment, and inventions "which combine a natural element with a technical process enabling it to be isolated or produced for an industrial application'. ${ }^{66}$ The Court further held that ' ... it is common ground that this provision [Article 6(1)] allows the administrative authorities and courts of the Member States a wide scope for manoeuvre in applying this exclusion'. ${ }^{67}$ According to the Court, a 'wide scope of manoeuvre' and discretion was ' ... necessary to take account of the particular difficulties to which the use of certain patents may give rise in the social and cultural context of each Member State'. ${ }^{68}$ Although the EU Court did not refer to the ECHR or the ECtHR jurisprudence, the principle of granting Member States a margin of appreciation in defining the scope of application of Convention rights is a fundamental principle of Convention law. ${ }^{69}$ The principle has particular significance in the interpretation of fundamental rights touching on morally sensitive matters on which there is no consensus in Europe but a diversity of national moral and religious cultures instead. ${ }^{70}$ The margin of appreciation ' ... gives the flexibility needed to avoid damaging confrontations between the Court and the Member States and enables the Court to balance the sovereignty of Member States with their obligations under the Convention'. ${ }^{71}$ The ECtHR has consistently applied the margin of

65. Referral Xa ZR 58/073 dated 17 December 2009. For a commentary on the background to the referral, see M Grund (patent attorney for Oliver Brüstle) and S Farmer, 'The EU Stem Cell Debate: Can Patenting Stem Cell Inventions be done Morally?' (2011) 11(6) Bio-science Law Review 187.

66. Paras 71 and 72 .

67. Para 37.

68. Para 38.

69. See S Greer, The Margin of Appreciation: Interpretation and Discretion under the European Convention on Human Rights (Council of Europe, 2000), and discussion of the legal basis of the doctrine of the margin of appreciation on the Council of Europe's website at <http://www.coe.int/t/dghl/cooperation/lisbonnetwork/themis/ECHR/Paper2_en.asp>.

70. The level of consensus may be found to vary and in some cases be altogether irrelevant. For instance, in Alekseyev v Russia (Nos 4916/07, 25924/08, 14599/09, 21 Oct. 2010) the Grand Chamber of the ECtHR found that Russia had violated the applicant's right to peaceful assembly under Article 11 in banning a gay rights activist from holding a gay parade and laying down flowers at the tomb of the unknown soldier. Whilst recognizing that a consensus had yet to emerge on matters such as civil marriage and partnerships, the Court noted that the absence of a consensus on these questions was of no relevance to the instant case '... because conferring substantive rights on homosexual persons is fundamentally different from recognizing their right to campaign for such rights'. The case is discussed by A Mowbray, 'European Court of Human Rights: May 2010-April 2011' (2011) 17(4) European Public Law 605. See also K Dzehtsiarou, 'Does Consensus Matter? Legitimacy of European Consensus in the Case Law of the ECtHR' (2011) (July) Public Law 534.

71. H Fenwick, Civil Liberties and Human Rights (Cavendish Publishing Limited, London 2005) at 34-7. 
appreciation doctrine in cases calling into question the compatibility of national laws on the right to life of human embryos and foetuses under Article $2 .{ }^{72}$ Thus, the interpretive approach adopted by the EU court in the Netherlands case is consistent with the ECtHR's on the interpretation of the scope of moral exclusions on biotechnological inventions in Article 6(1) of the Directive respecting the autonomy of Member States in areas where national moral and legal cultures differ.

By contrast, four years after the Netherlands case, the EU court held that Member States have no margin of discretion in the application and interpretation of the illustrative list of specific moral exclusions in Article 6(2) of the Directive in a case brought by the Commission against Italy (the 'Italy' case). ${ }^{73}$ The Commission had taken Italy to court for failing in its obligation to transpose the Directive into national law. ${ }^{74}$ In its defence, Italy had responded that its domestic patent law (in force) already complied with the Directive ${ }^{75}$ and that the practices covered in the list of specific exclusions were already prohibited under Italian research laws. Whilst reiterating that both the Treaty and the settled law of the Court allowed Member States to choose the precise form and method of implementing a Directive ${ }^{76}$ the Court nonetheless found that, in the instant case, the examples of specific exclusions in the Directive had to be transposed literally into national laws in order to achieve the purpose of the Directive, which was to clarify the legal protection of biotechnological inventions, and in order to prevent damage to the unity of the internal market. ${ }^{77}$ Thus, the Court ruled that:

Unlike Article 6(1) of the Directive, which allows the administrative authorities and courts of the Member States a wide discretion in applying the exclusion from patentability of inventions whose commercial exploitation would be contrary to ordre public (public policy) and

72. See A Mowbray, 'A Study of the Principle of Fair Balance in the Jurisprudence of the European Court of Human Rights' (2010) 10(2) Human Rights Law Review 289 and A Plomer, 'A Foetal Right to Life? The Case of Vo v France' (2005) 5(2) Human Rights Law Review 311. 73. Commission of the European Communities v Italian Republic Case C-456/03 ECR 2005, page I-0533.

74. As required by Article 15(1): 'Member States shall bring into force the laws, regulations and administrative provisions necessary to comply with this Directive not later than 30 July 2000. They shall forthwith inform the Commission thereof.'

75. Paras 32 and 45.

76. At para 51. The court acknowledged that 'according to the very words of the third paragraph of Article 249 EC, Member States may choose the form and methods for implementing directives which best ensure the result to be achieved by the directives, and that provision shows that the transposition of a directive into national law does not necessarily require legislative action in each Member State. ... [Provided that] the legal situation arising from those principles is sufficiently precise and clear and that the persons concerned are put in a position to know the full extent of their rights and, where appropriate, to be able to rely on them before the national courts (see, inter alia, Case 29/84 Commission v Germany [1985] ECR 1661, paragraphs 22 and 23, and Case C-233/00 Commission v France, cited above, paragraph 76).'

77. 'The Court has already held that, by requiring the Member States to protect biotechnological inventions by means of their national patent law, the Directive aims to prevent damage to the unity of the internal market which might result from the Member States' deciding unilaterally to grant or refuse such protection (Case C-377/98 Netherlands v Parliament and Council [2001] ECR I-7079, paragraph 18). In so doing, the Directive seeks, as is apparent from the fourth, fifth and sixth recitals in its preamble, to clarify the legal protection of biotechnological inventions in a context marked by differences between national laws and practices that could well become greater, in particular as a result of national case-law interpreting those laws.' (Para 58.) 
morality, Article 6(2) allows the Member States no discretion with regard to the unpatentability of the processes and uses which it sets out, since the very purpose of this provision is to give definition to the exclusion laid down in Article 6(1) (see, to this effect, Netherlands v Parliament and Council, paragraphs 37 to 39). ${ }^{78}$

The Court specifically approved the AG's Opinion that:

This uncertainty constitutes a breach of the Directive all the more because Article 6(1) thereof itself states that the commercial exploitation of an invention is not to be deemed contrary to ordre public or morality merely because it is prohibited by law or regulation. As the Advocate General has correctly observed in point 55 of his Opinion, this statement is to be interpreted as requiring express transposition of the principle that commercial processes involving the use of human embryos are not patentable. ${ }^{79}$

Are the two rulings in the Netherlands and Italy case inconsistent in both granting and not granting a margin of discretion to Member States in the application of moral exclusions in the Directive?

Arguably, there is no contradiction between the two judgments, if the two parts of Article 6 are interpreted and applied as the Technical Board of Appeal (TBA) of the EPO did the corresponding EPC rules in the Oncomouse II case. ${ }^{80}$ If a case falls within one of the four categories of exceptions, then it must ipso facto be denied a patent. However, cases not falling within the limited exclusions must then be considered under the general exclusion (in Article 6(1) of the Directive). As noted by the TBA, there are thus, in effect, two quite different type of objections under Article $6-$ an objection which requires only that the invention is assessed as to whether or not it falls in one of the four limited categories (under Article 6(2)), and a 'real' moral objection which requires an assessment as to whether or not exploitation of the invention would be contrary to ordre public or morality. Member States must be given a (wide) margin of appreciation in relation to the application of the general moral exclusion - as per the Netherlands case. No margin of discretion is given under Article 6(2) because the applicable test is NOT moral but definitional.

Furthermore, the drafting history of the Directive also shows that the specific exclusion on industrial and commercial uses of human embryos was intentionally narrowly drawn by the legislator in order to limit its reach and ensure that inventions and uses of human embryos which are lawful in Member States were not rendered unpatentable by the exclusion. ${ }^{81}$ The words 'industrial' and 'commercial' are not superfluous, but are to be interpreted literally.

Thus, absence of discretion in the application of the specific exclusions in no way removes the wide margin of discretion or appreciation left to Member States in the application of moral exclusions. By contrast, the CJEU ruling in the Brüstle case makes it difficult to read the trio of cases on the Directive in a consistent way. Both the Netherlands and Italy cases are cited by the Grand Chamber of the CJEU in the Brüstle case, but arguably applied in a manner which produces a paradoxical result which is at odds with the Court's approach in the earlier cases.

78. At para 78 .

79. At para 82 .

80. T315/03 (Oncomouse II) O.J.E.P.O 2005, p 246. Headnote II and 10.1.

81. See G Porter, 'The Drafting History of the European Biotechnology Directive', in A Plomer and P Torremans (eds), Embryonic Stem Cell Patents: European Law and Ethics (Oxford University Press, Oxford 2009) 3-26. 


\section{The Brüstle case $^{82}$}

The questions raised in the Brüstle preliminary ruling concern the scope of exclusion of the prohibition on patents on 'industrial and commercial uses of human embryos' in Article 6(2)(c) of the Directive, and specifically the meaning and scope of application of the terms 'human embryo' and 'industrial and commercial uses' in the exclusion. The reference was made in proceedings brought by Greenpeace seeking annulment of a German patent held by Oliver Brüstle. The patent relates to neural precursor cells and the processes for their production from embryonic stem cells and their use for therapeutic purposes. ${ }^{83}$ On application by Greenpeace, the Bundespatentgericht (Federal Patent Court) ruled that the patent at issue was invalid in so far as it covers precursor cells obtained from human embryonic stem cells and processes for the production of those precursor cells. ${ }^{84}$ Oliver Brüstle appealed against that judgment to the German Bundesgerichtshof (Federal Court of Justice) which referred the case for a preliminary ruling on the interpretation of Article 6(2)(c) of the Directive to the CJEU. ${ }^{85}$

The Grand Chamber of the CJEU reasoned that in order to give effect to the Directive, which was intended to unify patent law in Europe in order to avoid damage to the internal market caused by differences in national laws, ${ }^{86}$ and because of 'the fact that Article 6(2) of the Directive does not allow the Member States any discretion', it is necessary to give a European wide, uniform interpretation of the terms 'human

82. C-34/10. The case for a preliminary ruling concerns the interpretation of Article 6(2)(c) of Directive 98/44/EC of the European Parliament and of the Council of 6 July 1998 on the legal protection of biotechnological inventions (OJ 1998 L 213, p 13; 'the Directive').

83. The German patent was filed on 19 December 1997. It concerns isolated and purified neural precursor cells, processes for their production from embryonic stem cells and the use of neural precursor cells for the treatment of neural defects. It is claimed in the patent specification filed by Mr Brüstle that the transplantation of brain cells into the nervous system is a promising method of treatment for numerous neurological diseases.

84. On the basis of Paragraph 22(1) of the Patentgesetz transposing into German law Article 6(2)(c) of the Directive.

85. Specifically: 'In the view of the referring court, the outcome of the application for annulment depends on whether the technical teaching of the patent at issue, in so far as it concerns precursor cells obtained from human embryonic stem cells, is excluded from patentability under Paragraph 2(2), first sentence, point 3, of the Patentgesetz. The answer to that question depends in turn on the interpretation which should be given in particular to Article 6(2)(c) of the Directive' (para 20).

The specific questions were:

'What is meant by the term 'human embryos' in Article 6(2)(c) of [the Directive]?

(a) Does it include all stages of the development of human life, beginning with the fertilisation of the ovum, or must further requirements, such as the attainment of a certain stage of development, be satisfied?

(b) Are the following organisms also included:

- unfertilised human ova into which a cell nucleus from a mature human cell has been transplanted;

- unfertilised human ova whose division and further development have been stimulated by parthenogenesis?' (para 23 of the Grand Chamber ruling in Brüstle).

86. The Court noted recitals 3 and 5-7 in the preamble to the Directive where it seeks, by a harmonization of the rules for the legal protection of biotechnological inventions, to remove obstacles to trade and to the smooth functioning of the internal market that are brought about by differences in national legislation and case-law between the Member States, and, thus, to encourage industrial research and development in the field of genetic engineering (see, to that effect, Netherlands v Parliament and Council, paragraphs 16 and 27) (para 27). 
embryo' ${ }^{87}$ In the Court's view 'even though the Directive did not expressly define the concept of embryo, 'the only possible interpretation of that concept is European and unified' ${ }^{88}$ Such a uniform application was also consistent with the principle of equality and settled law whereby the terms of a provision of European Union law which makes no express reference to the law of the Member States must normally be given an independent and uniform interpretation throughout the European Union for the purpose of determining its meaning and scope ${ }^{89}$ The Court thus concluded that:

Although the text of the Directive does not define human embryo, nor does it contain any reference to national laws as regards the meaning to be applied to those terms. It therefore follows that it must be regarded, for the purposes of application of the Directive, as designating an autonomous concept of European Union law which must be interpreted in a uniform manner throughout the territory of the Union. ${ }^{90}$

The Court acknowledged that 'the definition of human embryo is a very sensitive social issue in many Member States, marked by their multiple traditions and value systems', but justified the adoption of a European, autonomous, uniform definition as required for the limited purposes of giving the Directive a 'legal interpretation' as distinct from questions of a 'medical or ethical nature' which the Court was not called upon to answer. ${ }^{91}$ Yet, the adoption of a judicially constructed 'autonomous' definition of the term 'human embryo' in circumstances where there is no legal (or moral) consensus amongst Member States on such a definition ${ }^{92}$ seems to fly in the face of the stated aim of the Directive in paragraph 8 of the Recitals whereby it is said that the 'legal protection of biotechnological inventions does not necessitate the creation of a separate body of law in place of the rules of national patent law'.

The Grand Chamber not only introduced an autonomous EU uniform definition of the terms 'human embryo', displacing existing definitions in national patent laws, but went further and claimed that the EU legislature 'Intended to exclude any possibility of patentability where respect for human dignity could thereby be affected. It follows that the concept of "human embryo" within the meaning of Article 6(2)(c) of the Directive must be understood in a wide sense. 93 Accordingly, but without any reference to legal (as against 'medical or ethical') sources on the concept of human dignity in the treaties specifically mentioned in the Directive, particularly the ECHR, or the national constitutions of Member States or the Strasbourg Court jurisprudence, the Court adopted a very wide definition of the term 'human embryo" 94 and concluded that the reach of the

87. At para 21.

88. At para 21.

89. At para 25. The Grand Chamber drew attention, in particular, to Case 327/82 Ekro [1984] ECR 107, paragraph 11; Case C-287/98 Linster [2000] ECR I-6917, paragraph 43; Case C-5/08 Infopaq International [2009] ECR I-6569, paragraph 27; and Case C-467/08 Padawan [2010] ECR I-0000, paragraph 32.

90. Para 26.

91. Para 30.

92. See A Hellstadius, 'A Comparative Analysis of the Implementation of the Directive's Morality Clause', in A Plomer and P Torremans (eds), Embryonic Stem Cell Patents: European Law and Ethics (Oxford University Press, Oxford 2009).

93. Para 34.

94. Any human ovum 'must, as soon as fertilised, be regarded as a 'human embryo' within the meaning and for the purposes of the application of Article 6(2)(c) of the Directive, since that fertilisation is such as to commence the process of development of a human being' (para 35). Furthermore, 'that classification must also apply to a non-fertilised human ovum into which 
specific exclusion on industrial and commercial uses of human embryos was intended by the legislature to preclude patenting research uses involving destruction of human embryos, as these are contrary to human dignity.

In the Court's view, the specific exclusion also extended to any downstream uses of hESC lines or cells, including therapeutic products whose derivation originally required the destruction of human embryos, irrespective of how far removed the application may be from the originally 'morally tainted' use:

Accordingly, on the same grounds as those set out in paragraphs 32 to 35 above, an invention must be regarded as unpatentable, even if the claims of the patent do not concern the use of human embryos, where the implementation of the invention requires the destruction of human embryos. In that case too, the view must be taken that there is use of human embryos within the meaning of Article 6(2)(c) of the Directive. The fact that destruction may occur at a stage long before the implementation of the invention, as in the case of the production of embryonic stem cells from a lineage of stem cells the mere production of which implied the destruction of human embryos is, in that regard, irrelevant. ${ }^{95}$

Arguably, had the CJEU adverted to the primary legal sources which are specifically mentioned in the Directive, and followed the principles of its own settled law on the interpretation of fundamental rights, it could not have reached the same conclusions. As it stands, the judgment is not only inconsistent with the earlier jurisprudence of the Court but with the Treaties and settled law on the rights of the embryo in Europe.

Notwithstanding the Court's claim that its interpretation of Article 6(2)(c) follows both the Netherlands and Italy cases, the reality is that an exclusion which was intended by the legislature to be interpreted strictly and narrowly to include only 'industrial and commercial uses of human embryos' has been extended by the Court, well beyond its literal meaning to include not only 'industrial and commercial uses of human embryos' but cell cultures and cell lines obtained by the destruction of human embryos, as well as all downstream therapeutic products using the cells, on the basis of an interpretation of human dignity which has no legal basis in the EU or CoE legal orders, and is wholly at odds with the legal and political reality on the level of protection granted to the human embryo across Member States in Europe. Contrary to the Court's view, uses of human embryos in research, particularly 'spare IVF embryos', including their destruction, are considered morally and legally permissible in a substantial number of countries in Europe. ${ }^{96}$ Furthermore, when opponents of research on human embryos sought to introduce exclusions to this effect in the EU Directive on Human Tissue and Cells (2004) and the Regulations on Advanced

the cell nucleus from a mature human cell has been transplanted and a non-fertilised human ovum whose division and further development have been stimulated by parthenogenesis, although those organisms have not, strictly speaking, been the object of fertilisation, due to the effect of the technique used to obtain them they are, as is apparent from the written observations presented to the Court, capable of commencing the process of development of a human being, just as an embryo created by fertilisation of an ovum can do so' (para 36). Finally, 'any human ovum after fertilisation, any non-fertilised human ovum into which the cell nucleus from a mature human cell has been transplanted and any non-fertilised human ovum whose division and further development have been stimulated by parthenogenesis constitute a "human embryo" within the meaning of Article 6(2)(c) of the Directive' (para 38).

95. Para 49.

96. See R Isasi and B Knoppers, 'Towards Commonality? Policy Approaches to Human Embryonic Stem Cell Research in Europe', in A Plomer and P Torremans (eds), Embryonic Stem Cell Patents: European Law and Ethics (Oxford University Press, Oxford 2009). 
Therapies (2007), they were unable to gather sufficient support in the European Parliament. Notwithstanding the efforts of religious and political groups to prohibit authorization and marketing of products based on human embryonic or foetal cells and tissues, there was no consensus to this effect in the European Union. Accordingly, both the Directive on Human Tissue and Cells (EUDHTC) ${ }^{97}$ and the Regulations on Advanced Therapy Medicinal Products (ATMP) ${ }^{98}$ adopt a default permissive approach, deferring to Member States on the moral and legal parameters of research and commercial uses of human embryos and embryonic tissues and cells. ${ }^{99}$ As a result of the Grand Chamber ruling, research and commercial uses of hESC cells which are permissible under EU law, in recognition and respect for the diversity and plurality of moral and religious cultures and the autonomy of Member States, will be unpatentable because the Grand Chamber decided that the specific prohibition in the Directive reflects a uniform European view of human dignity and its extension to the human embryo.

Yet, not only is the ruling internally inconsistent within EU law and the earlier jurisprudence of the Court, the ruling is also inconsistent with the settled law of the Strasbourg Court on the level of legal protection of the human embryo required of Member States to ensure compliance in respect of the right to life protected by Article 2 of the Convention. The jurisprudence of the ECtHR, on the scope of application of Article 2 to human foetuses and embryos has consistently reiterated the 'margin of appreciation' doctrine in relation to Article $2 .{ }^{100}$ In the leading case of VO v France, heard by the Grand Chamber in 2004, ${ }^{101}$ the Court refused to find that the failure by French law to criminalize grossly negligent conduct by a doctor which caused the death of a viable and healthy 20 -week-old foetus, constituted a violation of Article 2. Reviewing the existing case law, the court reasoned that it was, in effect, called in to intervene in the debate as to who is a person and when life begins, the definition of which lay within the margin of appreciation of Member States: ' ... The issue of when the right to life begins comes within the margin of appreciation which the Court generally considers that States should enjoy in this sphere ....'.102

The Court noted that there is no European consensus on the scientific and legal definition of the beginning of life. ${ }^{103}$ This was reflected in the absence of a consensus on the scope of application to the human embryo/foetus of the Council of Europe's Convention on Human Rights and Biomedicine (1996, ECHRB) and in recent reports on embryo research from the Council of Europe's Working Party on the Protection of the Human Embryo and Foetus, which was intended to draft a Protocol on the Human

97. Directive 2004/23/EC of the European Parliament and of the Council of 31 March 2004 on setting standards of quality and safety for the donation, procurement, testing, processing, preservation, storage and distribution of human tissues and cells, OJ L 102, 7.4.2004, pp 48-58.

98. Regulation (EC) No 1394/2007 of the European Parliament and of the Council of 13 November 2007 on advanced therapy medicinal products and amending Directive 2001/83/ EC and Regulation (EC) No 726/2004 OJ L 324, 10.12.2007, pp 121-37.

99. See A Plomer, 'Article 6(2)(c) of the Directive - Towards Systemic Legal Conflict', in A Plomer and P Torremans (eds), Embryonic Stem Cell Patents: European Law and Ethics (Oxford University Press, Oxford 2009).

100. See Plomer, 'A Foetal Right to Life: The Case of Vo v France', op cit, n 72.

101. Vo v France [GC], no 53924/00.

102. Para 82.

103. Para 82. 
Embryo to follow the ECHRB but was unable to reach a consensus. The Court noted that the Council of Europe's Working Party had concluded in its report of 2003 that whilst there was ' ... a broad consensus on the need for the protection of the embryo in vitro ... the definition of the status of the embryo remains an area where fundamental differences are encountered, based on strong arguments'. ${ }^{104}$ There was at best a common ground between Member States that the embryo/foetus belonged to the human race, ${ }^{105}$ and in recognition of the foetus's potential to become a person there existed some level of protection in domestic laws. ${ }^{106}$ In this light, the Court thus concluded, as it had in the previous cases, that it was inadvisable for it 'to answer in the abstract the question of whether the unborn child is a person for the purposes of Article 2 of the Convention' in the absence of a consensus on the moral and legal status of the human embryo. ${ }^{107}$

The Vo case was applied by the ECtHR in Evans $v U K^{108}$ where the applicant sought to rely on Article 2 to override the refusal of her partner to grant consent to the use of frozen embryos. In the first judgment concerning the right to life of the frozen embryo, the court unanimously held that the frozen embryo has no right to life. The Court's reasoning was succinctly put in one paragraph:

The Court recalls, however, that in VO v. France [GC], no. 53924/00, § 82, ECHR 2004 ... it [was] held that, in the absence of any European consensus on the scientific and legal definition of the beginning of life, the issue of when the right to life begins comes within the margin of appreciation which the Court generally considers that States should enjoy in this sphere. Under English law, as was made clear by the domestic courts in the present applicant's case (see paragraphs 16 and 21 above), an embryo does not have independent rights or interests and cannot claim - or have claimed on its behalf - a right to life under Article 2. ${ }^{109}$

The same reasoning was applied in the A.B. \& C. v Ireland judgment of 16 December $2010 .^{110}$

104. Report of the Working Party on the Protection of the Human Embryo and Foetus: Protection of the Human Embryo In Vitro (Council of Europe 2003). Cited at paras 83 and 39.

105. Para 84.

106. That is, in France and the UK in respect of inheritance without making it a 'person' with the 'right to life' for the purposes of Article 2. para 84.

107. Para 85.

108. Evans v UK, no. 6339/05.

109. Para 46, my emphasis. Further, Evans $v U K$ also indicates that the scope of application of Article 18 in the Convention on Human Rights and Biomedicine (1996) has to be correspondingly qualified. Article 18(1) of the ECHRB provides that: ' 1 . Where the law allows research on embryos in vitro, it shall ensure adequate protection of the embryo. 2. The creation of human embryos for research purposes is prohibited'.

It is worth noting that Member States whose national laws (at the time of signature of the Treaty) permit the creation of human embryos for research purposes are allowed to enter a reservation to this effect under Article 36. The reservation is consistent with the margin of appreciation conferred on Member States on the level of protection to be granted to the embryo. Regarding Article 18(1), it is unclear from the wording of the Article whether it necessarily rules out research which has the effect of ending the life of the embryo, particularly when legislative provisions on 'spare' IVF embryos in many Member States require their destruction after a period of time if unused. Evans $v$ UK suggests that such research may not necessarily constitute a violation of Article 2.

110. A.B. \& C. v Ireland [2010] ECHR 2032. 


\section{PART 4 - FROM THE CJEU TO THE ECtHR?}

Whilst there is nowhere to appeal the judgment of the Grand Chamber of the CJEU within the European Union legal system, the judgment nevertheless raises important questions about the compatibility of the Directive - as interpreted by the CJEU with the ECHR and settled law of the Strasbourg Court. The next section explores a range of possible legal avenues for judicial review by the ECtHR under the Draft Accession Agreement and under the existing division of the EU and CoE legal orders, and suggests that accession under the proposed terms may open up the range of legal recourses available to Member States and individual applicants.

The Brüstle case falls into the category of applications canvassed in the draft agreement, where a Member State is under an obligation to align domestic law ${ }^{111}$ with EU law in circumstances where there is a question as to the compatibility of EU law with the provisions in the Convention. In particular, the Brüstle ruling has the effect of leaving Member States with no discretion as to the scope of application of the specific exclusion in Article 6(2)(c), in a manner which divests them of their wide margin of appreciation on the application of the level of legal protection required of Member States to comply with their obligations under Article 2 of the Convention in the settled law of the ECtHR. A Member State seeking to challenge the compatibility of the Brüstle ruling with Article 2 ECHR would have to argue either that the restraint imposed by the CJEU judgment is illegitimate, and/or, if legitimate, in breach of the Convention because the means by which to achieve the goals identified by the CJEU are disproportionate to the aim. The 'proportionality' principle is particularly pertinent in this case. Whilst not expressly mentioned in the Convention, the 'proportionality' 112 or 'fair balance' principle has nevertheless come to be recognized as one of the central principles guiding the interpretation of the Convention by the Strasbourg Court. ${ }^{113}$ The principle has been specifically relied upon by the Court in the interpretation of Articles which permit broadly framed derogations or limitations on the protection of certain fundamental rights such as Articles 8 or 11, providing the derogations are legitimate and that they fulfil certain stated objectives such as public order, national security or public morality, as long as these are necessary in a democratic society. ${ }^{114}$

111. In this instance the UK Patents Act.

112. A parallel principle is also found in the primary sources of EU law, particularly Article 6(3)(b) of the Treaty of the European Union (as amended by Amsterdam 1997) incorporated into Article 5 TEU. The principle of proportionality requires that any action by the Community shall not exceed what is necessary to achieve the objectives of the Treaty Article 5(4) TEU. The application of the principle is governed by the Protocol on the principles of subsidiarity and proportionality in the Treaty of Lisbon (2007) OJ C 306, 17.12.2007, pp 150-52.

113. For a classic discussion by senior judges and scholars see E Ellis, The Principle of Proportionality in the Laws of Europe (Hart, Oxford 1999).

114. The case law illustrating the application of the principle in relation to specific Articles, particularly Articles 8 and 11 is vast. See D Harris, M O'Boyle, E Bates and C Buckley, Harris, O'Boyle \& Warbrick: the European Convention on Human Rights (Oxford University Press, Oxford 2009).

A much disputed and infamous application of the principle may be found in Osman $v U K$ [1998] EHRR 101 where the ECtHR held that the failure of English law to grant a civil remedy to the applicant in an action in negligence against the police conferred 'blanket immunity' and as such was in breach of Article 6. The judgment was strongly criticized by senior judges in the UK for disclosing a lack of understanding of domestic law by the Strasbourg judges - subsequently acknowledged by the Strasbourg Court in $Z v U K$ (29392/95). A similar approach was taken by 


\section{Right to property and right to life}

Articles whose wording facilitates the Court's application of the margin of appreciation doctrine and proportionality principle include Article 1 of the 2001 Protocol on the Enforcement of certain Rights and Freedoms not included in the Convention, whereby:

Every natural or legal person is entitled to the peaceful enjoyment of his possessions. No one shall be deprived of his possessions except in the public interest and subject to the conditions provided for by law and by the general principles of international law.

The preceding provisions shall not, however, in any way impair the right of a State to enforce such laws as it deems necessary to control the use of property in accordance with the general interest or to secure the payment of taxes or other contributions or penalties.

The Strasbourg Court has interpreted Article 1 very broadly, and given Member States a wide margin of appreciation in the determination of the 'public interest' or 'general interest', ${ }^{115}$ applying three 'distinct' but interconnected rules:

the first rule, set out in the first sentence of the first paragraph, is of a general nature and enunciates the principle of the peaceful enjoyment of property; the second rule, contained in the second sentence of the first paragraph, covers deprivation of possessions and subjects it to certain conditions; the third rule, stated in the second paragraph, recognises that the Contracting States are entitled, amongst other things, to control the use of property in accordance with the general interest $\ldots{ }^{116}$

The first issue which arises with regard to the question of the possible application of Article 1 of Protocol No. 1 to the Brüstle exclusion is whether the rights protected by Article 1 extend to intellectual property rights and patents. In Smith Kline and French Laboratories Ltd $v$ the Netherlands, ${ }^{117}$ the Commission held that patents fall within the scope of the term 'possessions' in Article 1 of Protocol No. 1. The case was followed in Lenzing AGv the United Kingdom, ${ }^{118}$ which explained that the 'possession' was not the patent as such, but the applications made by the applicant company in civil

the Court in Hirst v UK (No 2) ([2005] ECHR 681), holding that a blanket ban on prisoners' right to vote was contrary to Article 3 of the First Protocol. By contrast, Pretty v UK ((2346/ 02) [2002] ECHR 423) is an example where the Court found that the criminalization of assisted suicide in English law was neither illegitimate nor disproportionate, and therefore did not violate Article 8.

115. For an enlightening comprehensive analysis of Article 1 and its application to intellectual property rights by the Strasbourg court, see L Helfer, 'The New Innovation Frontier: Intellectual Property and the European Court of Human Rights' (2008) 49(1) Harvard International Law Journal 2. For a discussion of the Court's general approach to Article 1 see T Allen, 'Compensation for Property under the European Convention on Human Rights' (2006) 28 Michigan Journal of International Law 287.

116. Grand Chamber judgment, para 62: "The three rules are not, however, "distinct" in the sense of being unconnected. The second and third rules are concerned with particular instances of interference with the right to peaceful enjoyment of property and should therefore be construed in the light of the general principle enunciated in the first rule (see, among other authorities, James and Others $v$ the United Kingdom, 21 February 1986, § 37, Series A no. 98, in which the Court reaffirmed some of the principles it had established in its judgment in Sporrong and Lönnroth v Sweden, 23 September 1982, § 61, Series A no. 52; see also Beyeler, cited above, § 98)'.

117. No. 12633/87, Commission decision of 4 October 1990, Decisions and Reports 66, at 70. 118. No. 38817/97, Commission decision of 9 September 1998, unreported. 
proceedings in which it had sought to bring about changes to the British system for registering patents. ${ }^{119}$

Applying the above, the claim for judicial review of the CJEU ruling by the ECtHR could theoretically run as follows. Assuming EU law, specifically in this instance the Directive and its interpretation by the CJEU, may legitimately limit the scope of protection of intellectual property rights and specifically rights over biotechnological inventions in the national laws of Member States for the purpose (internal to EU law) of avoiding damage to the internal market caused by differences in domestic laws, ${ }^{120}$ limitations on those rights based on 'public order' or morality under Article 6 would nevertheless have to be consistent with the wide margin of appreciation afforded to Member States to control the grant of property rights in accordance with the 'public interest' or 'general interest' in Article 1 of the Protocol, providing that the objectives are legitimate and the means proportional to the goals.

It could be conceded, for the purpose of this argument, that it may be legitimate for EU law to require Member States to adopt a uniform 'autonomous' definition of the terms 'human embryo' strictly for the purpose of giving effect to the specific exclusion in Article 6(2)(c) of the Directive, and in order to ensure that the provision is not frustrated. On the other hand, the extension of the specific exclusion containing the term 'human embryos' not only to patents on 'uses of human EMBRYOS' but to embryonic cells or cell lines and products whose derivation requires destruction of a human embryo, appears disproportionate. The extension arguably overreaches the narrow terms of the exclusion on the basis of an inputted moral consensus in Europe that respect for human dignity is violated by uses, including research uses, which are destructive of human embryos. In so doing, the CJEU interpretation of the terms of the exclusion leaves no discretion to Member States, in disregard of the diversity of national moral and legal cultures on the legal protection of the embryo and contrary to settled Convention law in Article 2.

Additional support for the above analysis may also be found in the Charter of Fundamental Rights of the European Union ${ }^{121}$ and the Convention on Human Rights and Biomedicine (1996, hereafter ECHRB). Whilst the Grand Chamber did not advert to the applicability of either of these instruments in the Brïstle judgment, both instruments are cited in European Union Directives and Regulations concerning human tissue and cells, including reproductive cells. The Preamble of the EU Directive on Human Tissue and Cells (EUTCD, 2004) specifically recalls the ECHR (1950), and

119. The cases are reviewed by the Grand Chamber in Anheuser-Busch Inc. $v$ Portugal (judgment of 11 January 2007). The court notes the Commission's conclusion that in Lenzing $v$ UK there had been no interference with the applicant company's right to the peaceful enjoyment of its possessions, as it had been given an opportunity to set out its claims concerning the patent to a court with full jurisdiction. The Grand Chamber also noted at para 69 that in British-American Tobacco Company Ltd v the Netherlands, the Commission expressed the opinion that Article 1 of Protocol No. 1 did not apply to an application for a patent that had been rejected by the competent national authority. It stated: ' $\ldots$ the applicant company did not succeed in obtaining an effective protection for their invention by means of a patent. Consequently, the company were denied a protected intellectual property right but were not deprived of their existing property' (see British-American Tobacco Company Ltd $v$ the Netherlands, 20 November 1995, opinion of the Commission, §§ 71-2, Series A no. 331).

120. It is not clear whether the separate question of whether the adoption of an 'autonomous' definition did or did not fall within the scope of the Directive would be within the jurisdiction of the ECtHR - very likely not.

121. 01/12/2009; entry into force, see 12007L006 Art 6.2. 
states that the ECHRB and additional protocols are 'taken into account'. By contrast, the substantive provisions are intended to be 'consistent with' the Charter of Fundamental Rights of the European Union. ${ }^{122}$ Similarly, the ATMP Regulations (2007) proclaim respect for the fundamental rights and observance of the principles reflected in the Charter of Fundamental Rights of the European Union and 'takes into account' the ECHRB. ${ }^{123}$ The different language used could be read as indicating that the EU legislature intended the Charter's guiding influence to take precedence over the ECHRB, since the provisions in the Directive and Regulations are expressly intended to be 'consistent with' or 'observe' and 'respect' the rights enshrined in the Charter, but not necessarily in the ECHRB, which have only to be 'taken into account'. The enhanced status of the Charter vis-à-vis the $\mathrm{CoE}$ instruments is further reinforced in the subsequent Commission directive on quality and safety procedures which recalls only the Charter of Fundamental Rights. ${ }^{124}$

Whether or not the Strasbourg Court would concur with the implicit hierarchy of the two human rights instruments in EU law is an open question, which may turn not only on the origins of the instrument $(E U \vee C o E)$, but also on the relative legal weight of each instrument. Whilst the Charter is legally binding on Members of the European Union, ${ }^{125}$ the legal weight carried by the ECHRB is less certain and is heavily dependent on acquiring sufficient support in the way of ratifications from Member States and consistent State practice, which is to be regarded as reflecting a level of consensus amounting to customary law. Hitherto, the number of signatures and ratifications of the ECHRB have been overwhelmingly from the former communist countries ${ }^{126}$ whilst leading European States which have neither signed nor ratified the Convention include the UK, Germany and France. The absences reflect the historically contested nature of several provisions in the ECHRB which many States disputed at the time of the drafting as either too permissive or too restrictive. ${ }^{127}$ Amongst the contested clauses is Article 18(2) prohibiting the creation of human embryos for research purposes, whilst Article 18(1) provides that where research on human embryos is permitted it shall ensure adequate protection of the human embryo.

Arguably, it would be difficult to read Article 18 as indicative of a European consensus that research destructive of human embryos is contrary to human dignity for three reasons. First, as pointed out before, there is no settled State practice to evidence such a consensus - instead the political and legal reality is that such research is permitted in a substantial number of Member States in Europe. Secondly, as the Grand

122. EUCTD, Recital 22. The directive also recognizes the role of the opinions of the European Group on Ethics in Science and New Technologies (EGE) in evaluating all ethical aspects of biotechnology. The Directive states that EGE's opinions have been taken into account while drafting the directive (Recital 33).

123. ATR, Preamble, Article 8.

124. See Comm. Dir. 2006/86/EC, Recital 12: 'This Directive respects the fundamental rights and observes the principles recognised in particular by the Charter of Fundamental Rights of the European Union'.

125. Subject to the reservations entered by some States.

126. Seemingly, largely through a process of 'mimesis' and without parliamentary discussions, which has been interpreted as indicative of the political pressure on these States to accede to the ECHRB as a means of acquiring a legitimizing 'imprimatur' for accession to the EU. See F Millard, 'Rights Transmission by Mimesis: the Biomedicine Convention in Central Europe' (2010) 9(4) Journal of Human Rights 427.

127. Susan Millns, 'Consolidating Bio-Rights in Europe', in F Francioni (ed), Biotechnologies and International Human Rights (Oxford University Press, Oxford 2007) 75-84. 
Chamber noted in the $V O v$ France case, there is no consensus in Europe as to what level of legal protection is required for the human embryo. The Grand Chamber specifically noted that the Working Party on a Protocol on the human embryo, which was intended to follow the ECHRB, had to fold in 2003 because the group was unable to find sufficient common ground on the human embryo to draft a Protocol. Finally, the explanatory report to the ECHRB expressly notes that whilst the Convention is intended to guarantee the rights of 'everyone':

The Convention does not define the term 'everyone' (in French 'toute personne') ... In the absence of a unanimous agreement on the definition of these terms among member States of the Council of Europe, it was decided to allow domestic law to define them for the purposes of the application of the present Convention. ${ }^{128}$

This is particularly significant, as there is a presumption that the ECtHR is consistent with the main Treaty (ECHR), which also left the term 'everyone' undefined (including its scope in Article 2 protecting 'everyone's' right to life for the same reasons). Finally, the inclusion of references to ECHRB in the text of the Directive on Biotechnological Inventions (1998) was specifically contemplated at the time of the drafting of the Directive, and amendments to this effect were introduced but not adopted. Thus, whilst the ECHRB has been invoked by the ECtHR against Member States who have not ratified it, ${ }^{129}$ it is important to note that this was in the context of uncontroversial and longstanding internationally recognized principles on consent to treatment, in contrast to the contested and legally uncertain reach of the provisions on embryo research in Article 18 ECHRB.

Conversely, the practice of the ECtHR in relation to the EU Charter has been to work with a presumption that the Charter, which has been legally binding on Members of the EU since the adoption of the Lisbon Treaty, is intended to be consistent with the ECHR. ${ }^{130}$ Of particular significance in this context are two of the Charter's provisions. First, the explanatory report on Article 1 of the Charter declaring that human dignity is inviolable refers to the dignity of the human person consistently with the ascription of human dignity to persons already born in the 1948 Universal Declaration of Human Rights. Whilst the wording of a new wave of human rights instruments since UNESCO's adoption of the Human Genome Declaration (1992) and latterly the UNESCO Declaration on Bioethics (2006) has created some ambiguity as to whether the bearer of human dignity and rights may also include human embryos or foetuses, ${ }^{131}$ both these instruments explicitly state that they are intended to be consistent with the UDHR, which in any event has primacy from the perspective of international law. ${ }^{132}$ Furthermore, the explanatory notes to the EU Charter on Article 2 protecting everyone's right to life state that Article 2 of the Charter is intended to have the same meaning as Article 2 of the ECHR. Thus, the provisions of the Charter

128. Para 18, Explanatory Report.

129. Glass v UK, no 61827/00 and Pretty v UK, no 2346/02. For a discussion of the impact of the ECHRB in these cases see A Plomer, The Law and Ethics of Medical Research: International Bioethics \& Human Rights (Cavendish Publishing, London 2005).

130. See S Douglas-Scott, op cit, $\mathrm{n} 8$.

131. For a scholarly analysis of the historical and philosophical roots of 'human dignity' and the concept's indeterminate meaning in national constitutions and their judicial interpretation, see C McCrudden 'Human Dignity and Judicial Interpretation of Human Rights' (2008) 19 EJIL 655.

132. See H Schmidt, 'Whose Dignity? Resolving Ambiguities in the scope of "Human Dignity" in the Universal Declaration on Bioethics and Human Rights' (2007) 33 J Med Ethics 578. 
and the ECHRB point to a continuing lack of consensus and uniformity in Europe on the ascription of human dignity to human embryos and/or what legal implications this may entail. Together they provide considerable legal weight to displace the CJEU's curtailment of the margin of appreciation of Member States in this field. Finally, the provisions in Article 17(2) of the Charter on Protection of the Right to Property, whilst explicitly mandating that intellectual property shall be protected, in parallel to Article 1 of the Protocol, recognizes that the right may be restrained in the 'general interest'. In short, the spectrum of provisions in the additional human rights instruments of both the EU and the CoE strongly support the adoption of a 'balancing' and proportionate approach in the interpretation of the scope of exclusions on patents on biotechnological inventions in Europe against the 'wide' meaning of human dignity ascribed by the Grand Chamber to the human embryo. As it stands, the Brüstle judgment has granted legal recognition to the human embryo and a level of protection hitherto unrecognized in the settled law of the European Convention on Human Rights on the back of a Directive formally dealing with patents. From a human rights perspective, the judgment is an unprecedented and legally unjustified constitutional interference with the autonomy of Member States.

Once the EU is a party to the Convention, Member States (or individual applicants) will be able to bring a case against the EU and vice versa under Article 33 of the Convention. ${ }^{133}$ Until this happens, applications for alleged violations of the Convention would have to follow the standard route which allows individual applicants to call into question the compatibility of national laws with the Convention. Having established that Article 1 of the Protocol is engaged, the applicant would have to show that limitations of the right (ie in the UK Patents Act, based on the Brüstle ruling) are either illegitimate or disproportionate. The main difference between the two procedures is twofold: first, in the legal basis of the claim - which following accession could be framed directly as concerning the compatibility of EU law with the ECHR. By contrast, an individual claim under the existing dual EU/CoE legal orders would have to be based on breach of domestic national laws with the ECHR. Secondly, there would be a major difference in the legal outcome of the two procedures. Under the existing system, it would be the UK rather than the EU which would be found in breach of the Convention and would be legally bound to align its domestic law with the Convention. But this, of course, would bring the UK into conflict with the EU, and the EU would not be bound by the ECtHR. By contrast, under the terms of the Draft Accession Agreement, the EU would be legally bound by the decision of the ECtHR.

\section{CONCLUSION}

The analysis of the CJEU judgment in Brüstle highlights the sheer complexity of the unfolding legal map in Europe on the intersection between European Union law, Convention law and national laws. The case may be seen as a lens against which to gauge the range of questions and issues raised by the existing legal architecture of the European Union, and the implications of current proposals for the EU's accession to the ECHR. The discussion has tentatively explored how the legal routing of claims to test the consistency of EU law with human rights law may be affected by the proposed changes. But it should be remembered that this is unchartered legal territory, in a context where legal decisions may ultimately be shaped by the changing composition

133. Para 62; although note limitations on inter-party cases in paras 63-6. 
and membership of two supra-national courts in the light of the evolution of the political and religious map of Europe. The analysis also highlights the seriousness of the challenges ahead, as the approach taken by the CJEU in the Brüstle case sets it on a conflict path with the ECtHR, whilst statements issued by the Presidents of the two courts early this year indicate that the ECtHR has little inclination for a fight. Altogether, looking at the Brüstle case from the perspective of current debates on the role and competence of supreme national courts vis-à-vis two supra-national courts whose competence and political legitimacy is the subject of ongoing controversy, highlights the difficulties ahead. It also shows the potential threats to the rule of law created by the increasing complexity and volume of overlapping, intersecting and cross-cutting layers of national, EU and CoE laws. Looking ahead, the legal uncertainty created by the growth and complexity of European law could, paradoxically, pose a risk to both the economic competitiveness of Europe and the protection of fundamental human rights. 